\title{
Trnka Vaclav - Central European Anatomist and Medical Polymath of the Eighteenth Century
}

\author{
Kachlik D ${ }^{1}$, Varga I ${ }^{2}$, Zupanic $\mathrm{J}^{3}$, Szekely AD ${ }^{4}$ \\ Institute of Histology and Embryology, Faculty of Medicine, Comenius University in Bratislava, \\ Bratislava, Slovakia. ivan.varga@fmed.uniba.sk
}

\begin{abstract}
Vaclav Trnka from Křovice (1739-1791, in Latin: Wenzel Trnka Krzowitz) was a remarkable physician whose life serves as an example in the history of medicine by connecting major capital cities of Central Europe. In view of current geographical layout, he was born and brought up in the Czech Republic, graduated from University of Vienna in Austria, and was appointed Professor of the Anatomy at the newly established Faculty of Medicine of University of Nagyszombat, presently Trnava in Slovak Republic. When the University moved to Buda and later to Pest (today Budapest, Hungary), he was the first educator to introduce anatomy as a medical subject to be taught in a Hungarian medical school. He also was elected the Dean of Faculty of Medicine three times and in 1786-1787 he acted as Rector of then the Royal University of Pest. During his life, he published twenty-seven monographs dealing with different areas of clinical medicine, such as malaria (intermittent fever), diabetes, and rickets. Based on these monographs we can proclaim that Václav Trnka was a co-founder of modern infectology, diabetology and ophthalmology in Central Europe. Nowadays, artificial intelligence and bioinformatics are inseparable parts of modern health care system which help the transformation of big data into valuable knowledge. In the $18^{\text {th }}$ century, Professor Trnka owned more than 3,000 scientific books and had natural, innate intelligence and wisdom which made him a real "medical polymath". As a musician, Trnka also composed sixty-one canons, two of them long wrongly considered as Mozart's work. Despite the fact that Trnka is considered to be the founder of Hungarian anatomy education and a major medical figure of the eighteenth century Central Europe, no internationally acclaimed biographical record of his life or work has so far been published in English. Therefore, we would like to reintroduce Václav Trnka both as an anatomist and medical polymath, and to give an overview of the early days of anatomy teaching in present-day Slovakia and Hungary (Fig. 1, Ref. 27). Text in PDF www.elis.sk. KEY WORDS: Trnka from Křovice, anatomist, medical polymath, history of medicine.
\end{abstract}

\section{Introduction}

Vaclav Trnka (Wenzel Trnka; Trnka Venczel) (Fig. 1) came from a Bohemian noble family with several of his ancestors being royal officials. In 1629, the Trnka family was decorated by a coat of arms - the heraldic picture shows a green hill with a golden oak bush in blue field and received a predicate ' $\mathrm{z}$ Křovic' (from Krzowitz; Krzowitzi). Václav Trnka was born to Václav and Monica Trnka in Tábor (Bohemia), on 18 October 1739, although certain historical sources sometimes refer to 1738 as his year of birth, mistaking it with his elder brother's birthday who died as a two-month-old infant. According to Györy (1902), Václav Trnka

${ }^{1}$ Department of Anatomy, Second Faculty of Medicine, Charles University, Prague, Czech Republic, ${ }^{2}$ Institute of Histology and Embryology, Faculty of Medicine, Comenius University, Bratislava, Slovakia, ${ }^{3}$ Institute of World History, Faculty of Arts, Charles University, Prague, Czech Republic, and ${ }^{4}$ Department of Anatomy, Histology and Embryology, Faculty of Medicine, Semmelweis University, Budapest, Hungary

Address for correspondence: I. Varga, RND, PhD, Institute of Histology and Embryology, Faculty of Medicine, Comenius University in Bratislava, Sasinkova 4, SK-811 08 Bratislava, Slovakia.

Acknowledgement: The work presented in this study would not have been possible without the support from the Eurpean Regional Developmental Fund No. NFP 313010T431. spent his childhood in Hungary travelling with his parents between Kolozsvár (now Cluj, Transylvania, Romania), Nyitra and Nagyszombat (now Nitra and Trnava, Slovakia), and attended his elementary schools in Hungary which offers a reasonable explanation of his excellent command of Hungarian. There is also some uncertainty concerning his university studies. Several authors state that he first had been educated in Prague and then went to Vienna where he graduated from the medical school in 1770 (Högyes, 1896; Dohnány, 1971; Schultheisz and Magyar, 2005; Pásztor, 2007). Rozsívalová (1997), however, found no records of Václav Trnka in the Archive of Charles University, Prague. The lack of proof may be due to the fact that taking accurate records of scholarly activities, including the list of attending students, started only in 1793. It is believed that during his studies he had had excellent educators. Had he really attended the Charles University in Prague, his Anatomy Professor could have been Josef Tadeas Klinkos (1734-1776), who with a scientific interest has studied the anatomy of the abdomen together with the localization of herniae (Rozsívalová, 1997). Later, in Vienna, Trnka almost certainly has met the distinguished anatomist Johann Lorenz Gasser (1723-1765) but from the beginning he has been a dedicated follower of Gerard van Swieten whose son, Gottfried, was a good friend of his (Link, 2006; Kachlik et al, 2019). 


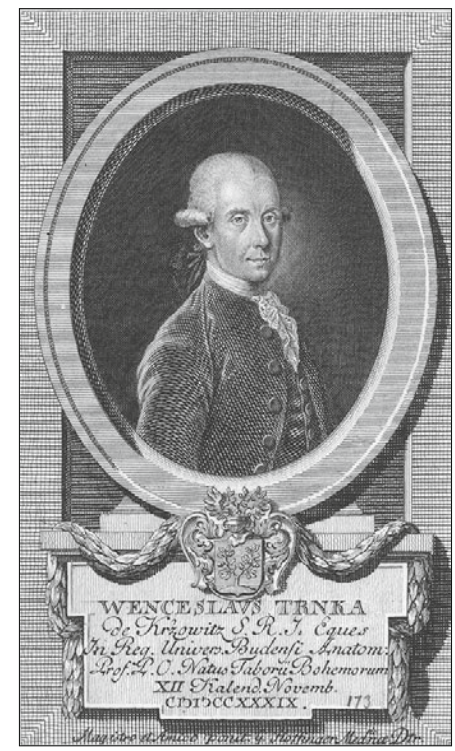

Fig. 1. Portrait of Václav Trnka.

Following van Swieten's recommendation, Trnka has started to work for his doctoral degree in the Vienna Military Hospital and was a devoted researcher of sciatica. On 23 January 1770, he defended his thesis 'De Morbo Coxario' (On Hip Disease) and earned his Doctor of Medicine degree from the Medical Faculty in Vienna. Not much later, on 29 October 1770 , also by the recommendation of van Swieten, he became Professor of Anatomy at the newly established Faculty of Medicine in Trnava (Rozsívalová, 1997).

Václav Trnka died on 12 May 1791 but his burial place unfortunately remains a mystery. He is one of the several former rectors of the current Eötvös Loránd University in Budapest, whose tomb has never been recovered (Kiss, 2012).

\section{The early days of Medical education in Trnava (Slovakia) and Budapest (Hungary)}

In the 17th-18th centuries the region of Upper Hungary, now known as the Slovak Republic, was a traditionally multicultural area. Here, the native Slovaks mingled with Hungarian and German-speaking communities. Since this region has not had its own higher education centres, medical and other scientific courses were only offered in more distant universities including Vienna, Prague, Krakow, Heidelberg, or Bologna. But not completely unbeknownst in our times either, many of the graduates of foreign universities had no inclination to return to their home countries, therefore the intellectual development of the region, together with the quality of health care, suffered from the lack of professionals (Chmelík et al, 2011). In 1635, Cardinal Péter Pázmány, the Roman Catholic Archbishop of Esztergom, member of the Jesuit order, decided to found a university in Upper Hungary in order to recatholise the region and improve the quality of education. The founder chart was signed by Emperor Ferdinand II. Cardinal Pázmány chose Trnava (Tyrnavia in Latin, or, Nagyszombat in Hungarian), the seat of a bishopric and archbishopric, which in the past had been called 'Parva Roma' (Little Rome) due to its numerous churches. Currently, Trnava is the seventh largest city in Slovakia. The newly established University of Trnava was first housed in a Jesuit convent and was soon recognised as an important educational institution in Central Europe. Worth noting that the Jesuit order (Societas Jesu) was suppressed by the order of Pope Clement XIV in 1773, although Empress Maria Theresa, Queen of Hungary, has tried to slow down the process. The majority of students and professors have come from different parts of the Habsburg Empire including the present-day Hungary, Slovakia, Croatia, and Transylvania / Romania and used Latin as a common language for tuition until 1844 (Chemlík et al, 2011). The first two faculties of the University of Trnava were the Faculty of Philosophy and the Faculty of Theology; in 1667, a new Faculty of Law was added; and in 1769 Empress Maria Theresa founded the Faculty of Medicine. At the same time the name was changed to Royal Hungarian University of Sciences (Királyi Magyar Tudományegyetem) (Online 1).

The history of the Faculty of Medicine of the University of Trnava lasted for only eight years between 1769 and 1777, then the university was moved to Buda (south-western half of Budapest today). The first Director (Dean) of the Faculty of Medicine in Trnava was Jan Gilg from Gilgenburg, a Moravian native, who has graduated from the Faculty of Medicine in Vienna and was appointed a city physician in Trnava (Měsíc, 2007). The Faculty of Medicine in Trnava was composed of five units, with three of them being concerned with theoretical teaching ('institutiones medicae') - Department of Anatomy, Department of Physiology and Pharmacology, and Department of Botany and Chemistry. The further two departments were more practically oriented clinics ('praxeos') - Department of Pathology and Internal Medicine, and Department of Surgery, Obstetrics and Ophthalmology, concerned with treating the sick. Each new department was led by a newly appointed young graduate of the Vienna Medical School. All of them were selected personally by Maria Theresa following a consultation with Gerhard van Swieten, the Empress's court physician and President of the Faculty of Medicine in Vienna. One of those five newly appointed professors was the young and ambitious Václav Trnka.

The Faculty of Medicine was launched on 7 November 1770 , and teaching was performed daily, except for Thursdays and Sundays. At that time lectures were presented as 'praelectiones' teachers have read the Latin text from the approved textbooks without being allowed to comment on the content or to speak about their opinions or experiences (Mráz et al, 2006). In 1775 this rule was changed thanks to a respected Viennese physician Anton von Störck and from that time on professors were allowed to compose their own textbooks, but these were still to be approved by the Director of the Faculty. Although the Faculty of Medicine worked only for a short time in Trnava, it contributed significantly to the history of education and the provision of quality health care in the territory of present-day Slovakia.

In particular, two graduates of the Medical Faculty in Trnava have to be mentioned. Jacob Reineggs (1744-1793) was a personal physician and friend of the last independent Georgian King Heraclius / Herakleitos II (1720-1793) in Tiflis and, for some time, 
his ambassador to Russia as well. In St. Petersburg, he ran the Institute for Education of Healers, where he died in 1793 (Tardy, 1957). Zachariás Teofil Huszty (Zacharias Gottlieb Huszty, 17541803/1806) with his work "Discours über medizinsche Police" as a Bratislava municipal doctor ranked among the pioneers of social hygiene and public health and was also a pioneer of smallpox vaccination of children (Kiss, 2014).

In 1777 , following the suppression of the Jesuit order, and mostly due to political reasons together with the unfavourable teaching conditions, the University was moved to the Royal Palace in Buda with the previous throne room serving as the Aula. Hence the patronage of the University had to be transferred from the Archbishop of Esztergom to the Sovereign of Hungary (Hungarian Catholic Lexicon, 2019), therefore the name was changed to Royal Hungarian University of Science (Királyi Magyar Tudományegyetem) which is still inscribed on the façade of the present building of the Department of Anatomy, Histology and Embryology of the Semmelweis University.

From our perspective it seems strange that in that era 'better teaching conditions" meant that the Faculty of Medicine owned 16 beds where medical students could learn in the university hospital. Even if it was a fairly low contingent, the City officials have firmly rejected the idea of joining further hospitals in the practical training (Pásztor, 2007).

In 1784 , seven years later, the University was moved to Pest on the other side of the river Danube - today both cities form part of Budapest, the capital of Hungary. Here again the name was changed to Royal University of Sciences of Pest (Pesti Királyi Tudományegyetem) and German has become the main language of instruction instead of Latin. By the personal order of the Emperor, Joseph II., the number of hospital beds was increased by twenty in 1786 .

In the course of the next 150 years the University has several times been renamed and the language of tuition has changed first from Latin to German and then to Hungarian. Between 1921 and 1950 it was renamed as the Royal Hungarian Péter Pázmány University of Sciences to bear the name of its initiator, Cardinal Péter Pázmány. After the Second World War the Theology and Medical faculties have been cut out of the body of the University to create separate universities. Finally, in 1950, the remaining faculties were named after Loránd Eötvös (1848-1919, the famous Hungarian physicist and politician, and since then the ELTE (Eötvös Loránd University of Sciences) saves the legacy of its predecessor, the University of Trnava.

\section{Václav Trnka and Anatomy education}

Václav Trnka was Head of the Anatomy Department at the Faculty of Medicine in Trnava from 1770. As he has pointed out in one of his written reports the lack of human cadavers caused extreme difficulties in teaching Human Anatomy, so he had to use his own previous prosections and was forced to introduce 'zootomy' - dissection of animal corpses, albeit with little success. It was again van Swieten who has come to his help by urging the lieutenancy council to issue a notice prompting the nearby larger cities like Bratislava (Pozsony) and Nitra (Nyitra) that the cadavers of executed criminals should be transferred to the so-called "Camera Anatomica" i.e., the Anatomy Department. However, due to the slow response from the aforementioned cities there was no immediate resolution of the problem. They also were short of the appropriate instruments so again Trnka had to compose a circular, addressed to the "higher authorities", listing twenty-two different dissection tools he was asking for. Alas, the response and financial help have only arrived several years later.

Trnka has taught anatomy according to the textbooks by Jacobus Benignus Winslow of Paris ('Expositio anatomica structurae corporis humani'), Bernardus Siegfried Albinus of Leyden ('De sceleto humano') and August Schaarschmidt of Berlin ('Anatomische Tabellen'). Trnka never wrote an Anatomy textbook himself, rather, he published many clinically-oriented monographs. After the release of the Latin version of the anatomical compendium ('Praelectiones anatomicae Editio nova, ex germanico traducta, correcta et aucta") in 1778 by Joseph Ferdinand Edler von Leber (1727-1808), a court surgeon of Maria Theresa, Trnka used mostly that particular 412-page work to teach anatomy (Schultheisz and Magyar, 2005; Mráz et al, 2006; Varga et al, 2018).

The improvement of conditions for teaching anatomy was not provided before a personal visit by the Emperor Joseph II at the University, whose order was to relocate the University to Pest. Here, in the former convent of the Jesuits, the Department of Anatomy was able to provide a larger space for teachers, a separate room for macerating the bones or having larger dissection rooms. Anatomy teaching was further improved due to the Emperor's personal gift of anatomical wax models. Several thousands of wax models depicting anatomical or pathological conditions were ordered and transported to Vienna from the workshop of Felice Fontana (1730-1805) in Florence, Italy. Many of those models are still on show in the Josefinum on the premises of the Medical University of Vienna. Unfortunately, except for one, most of these artistically and anatomically valuable wax models and manikins, stored in Pest, were destroyed during war conflicts. The only wax model to survive is on show in the Semmelweis Medical History Museum in Budapest (Pásztor, 2007). It is an amazing artwork illustrating the internal organs of a woman in great detail (Kachlík et al, 2019).

In 1786, after the death of a personal friend, and originally a native of Croatia, Michael Schoreticz, Václav Trnka left the Anatomy Department to take over the Chair in Pathology and Internal Medicine and later became Professor of Internal Medicine. According to records, Trnka was highly recognized by both, his colleagues and students. He became Dean of the Faculty of Medicine three times and in the years 1786-1787 he was even Rector of the university. During his tenure, he supervised the diploma theses of approximately 40 students.

\section{Vaclav Trnka's Scientific and Publication Activities}

Trnka has sported an extremely broad scope of interest and being a proliferous author published at least twenty-seven monographs on various topics. The copies of some of his original works 
are in possession of the Central Library of the Semmelweis University. As at that time it was common, Trnka authored his books in Latin, and his works were published in Vienna. Many of them, however, were translated to German to be published in Leipzig or Helmstädt. Worth mentioning that although he has been living for more than 20 years in Hungary and he allegedly liked and spoke very well the language himself, none of his books were translated to Hungarian.

His first known monograph 'Historia febrium intermittentium omnis aevi observata et inventa illustriora medica ad has febres pertinentia complectens' was published in 1775 . Here he describes in great detail that in malaria there is a periodically occurring, intermittent (alternating) fever and also suggests a treatment option using quinquina bark. Those days, malaria was a fairly frequent disease spreading to several areas of Hungary.

Trnka has adopted the following paragraph by Collin in his book: 'Tumores etiam varios intermittentem febrem discutare observatione constat. Virgo vestalis mamma sinistrae scirrhosae amputationem sustinuit. Haud ita mult post mamma altera fit scirrhosa, frustra mercurii erat usus internus externusque, licet diuturnus. Donec tertiana duplex superveniens, aliquot hebdomadum spatio, scirrhum in integrum discussit, teste Collin. Eadem quin plura de quartana notata sunt.' (From observations, it is known that intermittent fever eliminates various tumours. One nun survived the amputation of her left breast, in which a scirrhus was found. Despite the internal and external applications of mercury, soon the right breast became scirrhous as well. Finally, she suffered a three-day fever twice, lasting several weeks and a scirrhus was completely eliminated - as described by Collin. Several similar cases were also recorded in four-day fever.) Note: Scirrhus is a term of Latin origin, describing hard tumour, composed predominantly of connective tissue. Sebastian Collin was an Italian physician of the $16^{\text {th }}$ century, author of Tractatus de febribus intermittentibus (1553).

This monograph has been well received and had a very positive response, therefore it was swiftly translated to German. At that time, the journal 'Hallesche Gelehrte Zeitung" described the work as one of the most important new medical monographs. Later Trnka's work has also been recited by Friedrich Loeffler, a well-known German bacteriologist, recalling that Trnka had experimented with finding a treatment to malignant tumours by inoculating patients with malaria pathogens (Loeffler, 1901; Kubikova et al, 2019). Strange as it may sound from the perspective of current knowledge, it was actually confirmed that cancer cells and some parasites have similar antigenic characteristics. Different scientists reported a negative correlation between certain parasite infections and cancer development, so Osinaga (2007) hypothesizes that some antigens obtained from parasites could be good potential targets for cancer immunotherapy. On top of that, parasites as Trypanosoma cruzi or Toxoplasma gondii showed antitumour activity in animal models (Darani and Yousefi, 2012).

During his time in Trnava, Trnka wrote two more monographs. He devoted his work 'De diabete commentarius' (1776) to a German professor Ernst Gottfried Baldinger. According to some sources, he wrote the monograph on diabetes only in 1778 , i.e., at a time when he was already working in Buda. Therefore, Václav Trnka is considered to be not only the first Hungarian Anatomy professor, but also 'the first Hungarian diabetologist" by Kiss (Kiss, 2012). In his 'review" monograph 'Commentarius de tetano' (1777), he compiled the findings of 200 prominent physicians on the treatment of tetanus.

There is an outstanding work among the many interesting monographs written at the time while teaching at the University of Buda and later Pest. This scientific record entitled 'Historia amauroseos' (1781) is devoted to diseases of the eye leading to blindness. Further pathological conditions of the organ of vision are discussed in an accompanying book 'Historia ophthalmiae' written in 1783. Other extensive monographs include 'Historia cardialgiae' (1785) and 'Historia rachitidis' (1787) with the latter elaborating on the techniques of orthopaedic correction of body parts affected by rickets. Since in his time neither the aetiology nor the effective prevention/treatment of the condition has yet been discovered, therefore the diagnosis and/or treatment of rachitis were purely based on the emergence of visible symptoms. For instance, Trnka has recommended a medicinal bath containing thirty-one ingredients to treat children suffering from rickets not much different from the previous authors or even Paracelsus himself (Schultheisz, 1964). However, the real significance of this monograph lies with the fact that Trnka was able to summarise all contemporary knowledge on the disease and its treatment options as well as adopting excerpts from the work of the late English paediatrician and anatomist Francis Glisson (1599-1677).

Interestingly, the Central Library of the Semmelweis University in Budapest houses also three until now in literature not mentioned Trnka's monographs: Historia Leucorrhoeae (1781); Historia tympanitidis (1788); and Historia febris hecticae (1788) which contents have to be carefully studied in future.

According to Trnka, his most valuable work was a three-volume monograph dealing with haemorrhoids under the title 'Historia haemorrhoidorum omnis aevi observata medica continens'. This work, however, was only published in 1794, three years after his death thanks to a friend Francis (Ferenc) Schraud, Professor of Forensic Medicine in Pest.

For the sake of completeness only, although Trnka is considers to be the founder of anatomy education in Hungary as well as in Slovakia, he has never written his own anatomy textbook. From this point of view, the first anatomy textbook at the University of Trnava was written by Joseph Jakob Plenck (1735/1738-1807), an Austrian physician who worked as a Professor of Surgery and Obstetrics in Trnava. He is also considered to be the forerunner of modern European dermatology (Aliotta et al, 1994). Although Plenck was not a professional anatomist, as professor of the University of Trnava he wrote the anatomical textbooks "Primae lineae anatomes" and "Compendium anatomes for tyronibus", which were intended for surgeons-healers, pharmacists and obstetricians.

\section{Vaclav Trnka as Musician and his Passion for Books}

We do not know much about his private life, but beside his medical interests, Václav Trnka was an educated musician. He had 
good contacts with Gerard van Swieten's son, Gottfried, who has served as an Austrian diplomat as well as a financial mentor of several composers including Wolfgang Amadeus Mozart, Joseph Haydn and Ludwig van Beethoven. Václav Trnka himself has composed at least sixty-one canons to the text of Petro Metatasio out of which twelve were published by his widow, Theresa, fifteen years after his death (Link, 2006). Worth mentioning is that in 1988 Wolfgang Plath discovered that certain canons - Kanon KV 233 (382d) and Kanon KV 234 (382e) - formerly ascribed to Wolfgang Amadeus Mozart, were originally composed by Václav Trnka (Plath, 1991). Mozart has contributed to the composition only by changing the original Italian lyrics "Tu sei gelosa, è vero" to a rather explicitly rude German text 'Leck mir den Arsch fein recht schön sauber" (Lick me in the ass right well and clean), and 'So che vanti un cor ingrato' to 'Bei der Hitz im Sommer eß ich' (In the heat of summer I eat) (Ochs, 1964). In 1800, Mozart's widow Constanze sent these two canons as part of a bundle of canons to the publisher Breitkopf \& Härtel, who published them as Mozart's work four years later (Zaslaw, 2006).

As a University professor, Václav Trnka must have been a magnanimous and generous person who always have looked after his younger colleagues. In 1787 as Rector he urged the University to give a pay rise to the junior lecturers so that their annual income (150 forints) could reach the salary level of a so-called faculty servant (Schultheisz and Magyar, 2005). He has also been a great bibliophile and has spent a substantial part of his income to purchase and collect books. By the end of Trnka's life, he owned a library of more than 3,000 items listed in an accurately printed catalogue of about 110 pages (Catalogus librorum et auctorum medicorum Wenceslai Trnka). Nowadays, artificial intelligence and bioinformatics are inseparable parts of modern healthcare systems which help the transformation of big data into valuable knowledge (El-Hassoun et al, 2019). In the $18^{\text {th }}$ century the medical knowledge was also associated with possessing the newest scientific monographies and textbooks. The work of Václav Trnka may be an evidence that current artificial intelligence probably does not have as much "creativity" as human brain. Artificial intelligence is useful, but in other hand possibly dangerous in medicine, in order not to lose the natural, innate intelligence and wisdom that has a component of creativity with a huge impact.

When he died, according to his testament his books were sold in an auction and the University Library bought most of them for 3000 forints. Part of the money (1000 forints) was generously donated to a foundation to offer financial assistance to students coming from poor families. A further 1400 forints were left to help financing the foundation of a county hospital in Szekszárd in Southern Hungary. In 1992, to commemorate his good deed the grateful public of the city has placed a plaque on the wall of the hospital building with a Hungarian, Czech and Slovak trilingual inscription. It says: 'In honour of Václav Trnka, Professor of Medicine (1739-1791), who promoted the establishment of the first hospital in Tolna county and in memory of the common Czech-Slovak-Hungarian past".

The 18th century has been considered as the era of enlightenment throughout Europe leaving a mark in the field of natural sciences greatly helping a leap forward in medical sciences and diagnostics. It has brought new ideas to university teaching and revolutionised how knowledge was to be passed on by leaving the medieval traditions behind. In Central Europe, Gerard van Swieten had a pioneering role in introducing the new system and together with Václav Trnka they completely renewed and reorganised medical education in Austria and Hungary. With the spread of new ideas and the formation of Scientific Societies the procedure of sharing knowledge has been enhanced and access to high quality scientific reports has been made easier.

Václav Trnka was one of the leading medical scientists of the eighteenth century who has earned respect for his continuous work, extreme diligence and broad interest in the field of medicine. Being a curious experimenter and a keen educator he has written numerous publications to collect recent knowledge in his monographs. He was a popular University Professor with great empathy towards his colleagues and as a successful leader he continuously worked for improvement. Václav Trnka should undoubtedly be counted among the great personalities of anatomy and medicine in Central Europe, and it is our duty to keep his memory and legacy alive.

\section{References}

1. Aliotta G, Capasso G, Pollio A, Strumia S, de Santo NG. Joseph Jacob Plenck (1735-1807). Am J Nephrol 1994; 14 (4-6): 377-382.

2. Chmelík B, Rusnák M, Bučko L, O'Mullane M. Short history of the Faculty of Medicine at the historical University of Trnava: 375th anniversary of the University of Trnava, Slovakia. J Ecol Health 2011; 15 (6): 296-301.

3. Darani HY, Yousefi M. Parasites and cancers: parasite antigens as possible targets for cancer immunotherapy. Future Oncol 2012; 8 (12): $1529-1535$

4. Dohnány L. Professor Wenzel Trnka und seine Wissenschaftliche Werke. Communicationes de Historia Artis Med 1971; 57-59: 229-238.

5. El-Hassoun O, Maruscakova L, Valaskova Z, Bucova M, Polak S, Hulin I. Artificial intelligence in service of medicine. Bratisl Lek Listy 2019; 120 (3): 218-222.

6. Győry T. Emlékezzünk régiekröl. Trnka Venczel (Article in Hungarian; Remember the greats. Trnka Venczel). Orvosi Hetilap 1902; 46: 41.

7. Hőgyes E. Emlékkönyv a Budapesti Egyetem Orvosi Karának múltjáról és jelenéröl (Article in Hungarian, A Memorial Book about the Past and Present of the Medical Faculty of University in Budapest). Budapest: Magyar Orvosi Könyvkiadó Társulat, 1896, 138-139.

8. Hungarian Catholic Lexicon(Magyar Katolikus Lexikon). Bp.Lex. I, 375. Available at: http://lexikon.katolikus.hu/P/P\%C3\%A1zm\%C3\%A1ny\%20 P\%C3\%A9ter\%20Tudom\%C3\%A1nyegyetem.html [Accessed 2019-0108]

9. Kachlik D, Varga I, Székely AD. The legacy of Václav Trnka: modern medical education in Slovakia and Hungary in the eighteenth century. Surg Radiol Anat 2019; 41 (10): 1113-1116.

10. Kiss L. Vencel Trnka (1739-1791), the first Hungarian diabetologist, an author of a book on diabetes. Orvosi Hetilap 2012; 153 (24): 962-964.

11. Kiss L. Priekopníci vakcinácie na Slovensku (The pioneers of vaccination in Slovakia). Pediatr Prax 2014; 15 (1): 41. 
12. Kubikova E, Badidova J, Klein M, Beder I Jr, Benus R, Polak S, Varga I. Sentinel lymph node - historical background and current views on its significance in complex management of breast cancer patients. Bratisl Lek Listy 2019; 120 (6): 410-416.

13. Link D. È la fede degli amanti and Viennese operatic canon', in Simon Keefe (Hrsg.), Mozart Studies. Cambridge: Cambridge University Press, 2006, 109-136.

14. Loeffler F. Eine neue Behandlungsmethode des Karzinoms. Dtsch Med Wschr 1901; 42: 725E.

15. Měsíc C. Knihovna Dr. Gilga ve fondu Kroměřžšého zámku. In: Problematika historických a vzácných knižních fondů Čech, Moravy a Slezska: 16. ročník odborné conference. Olomouc: Vědecká knihovna Olomouc. 2007. Available at: http://www.vkol.cz/data/soubory/import/ konf16/04.pdf. [Accessed 2019-01-08]

16. Mráz P, Belej K, Beňuška J, Holomáňová A, Macková M, Šteňová J. Anatómia l'udského tela 2. (Textbook in Slovak, Anatomy of Human Body 2). Bratislava: Slovak Academic Press, 2006, 488 pp.

17. Ochs M. Grace notes. Notes, Second Series 1964; 47: 1326-1328.

18. Online 1. History of the Eötvös Loránd University. Available at: https://www.elte.hu/content/az-egyetem-tortenete.t.4? $\mathrm{m}=18$. [Accessed 2019-01-08]

19. Osinaga E. Expression of cancer-associated simple mucin-type Oglycosylated antigens in parasites. IUBMB Life 2007; 59 (4-5): 269-273.

20. Pásztor E. Orvosegyetemi oktatás hazánkban 1769 és 1971 között, különös hangsúllyal az anatómiára és a koponyára. (Article in Hungarian; The medical university education in our country between $1769-1971$ with emphasis on anatomy teaching and the skull). Commun Histor Artis Med 2007; 200-201: 5-34.
21. Plath W. Echtheitsfragen bei Mozart. II: Wenzel Trnka und die angeblichen Mozart-Kanons KV 233 (382d) und KV 234 (382e)', in Hanspeter Bennwitz et al. (Hrsg.), Opera incerta. Echtheitsfragen als Problem musikwissenschaftlicher Gesamtausgaben. Kolloquium Mainz 1988, Bericht im Auftrag des Ausschusses für musikwissenschaftliche Editionen der Konferenz der Akademien der Wissenschaften in der Bundesrepublik Deutschland; Akademie der Wissenschaften und der Literatur. Stuttgart: Steiner, 1991, 237-258.

22. Rozsívalová E. Václav Trnka z Křovic, profesor na lékařské fakultě v Trnavě, Budíně a Pešti (Article in Czech; Václav Trnka from Krzowitz, Professor at the Faculty of Medicine in Trnava, Buda and Pest). Dějiny věd a techniky $1997 ; 30$ (2): 75-80.

23. Schultheisz E, Magyar LA. Tanszékek és professzorok a Nagyszombati Egyetem Orvosi Karán 1769-1777. (Article in Hungarian; Departments and Professors of the Medical Faculty of University in Trnava, 1769-1777). Budapest: A Magyar Tudománytörténeti Intézet tudományos közleményei. 2005; 18.

24. Schultheisz E. Trnka Vencel. Orvosi Hetilap 1964; 48: 2293-2294.

25. Tardy L. Az elsö Magyar "sub auspiciis" orvosdoktor. (Article in Hungarian; The first Hungarian "sub auspiciis" doctor of medicine). Available at: http://www.orvostortenelem.hu/tankonyvek/tk-05/pdf/5.1.5/ 1957_006_007_tardy_lajos_elso_magyar.pdf [Accessed 2019-03-24]

26. Varga I, Repka M, Kachlík D, Székely A. Václav Trnka - the story of an almost forgotten Czech-Austria-Slovakia-Hungarian anatomist of the 18 th century, a founder of modern anatomy education in Hungary. FASEB J 2018; 32 (Suppl 1): Ib515.

27. Zaslaw N. The non-canonic status of Mozart's canons. Eighteenth Century Music 2006; 3: 109-123. 